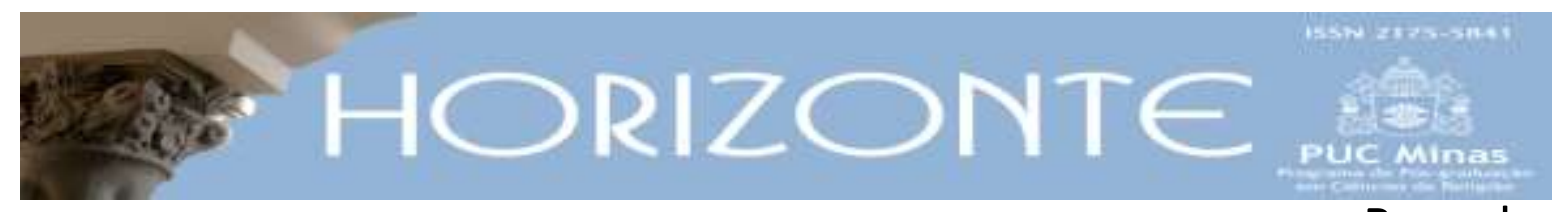

Resenha

(c) (i) DOI - 10.5752/P.2175-5841.2015v13n40p2320

\title{
Espiritualidade política
}

A propósito do livro de:

\section{HERNÁNDEZ PICO, Juan. No sea así entre ustedes: ensayo}

sobre política y esperanza. San Salvador, El Salvador: UCA

Editores, 2010. 700p. (ISBN: 978-99923-5930-3)

Pedro Assis Ribeiro de Oliveira*

O que fazer em tempos de desalento e cinismo, quando a globalização do mercado rompe os laços de solidariedade humana e favorece a indiferença diante do sofrimento alheio? Será que ainda faz sentido pensar uma Humanidade reconciliada consigo mesma e com a Terra, ou foi tudo um sonho da geração que viveu os anos dourados após a II guerra mundial? Será ingenuidade continuar a crer na profecia de um tempo quando Justiça e Paz se abraçarão, ou ela tem algum fundamento racional? Questões como estas perturbam quem se empolgou com a mensagem libertadora de Jesus de Nazaré e hoje tem a sensação de viver fora do mundo real, o mundo onde a felicidade é oferecida como um dentre os muitos produtos oferecidos pelo mercado. Juan Hernández Pico, jesuíta guatemalteco nascido no País Basco e com longa militância na assessoria às lutas populares na América Central, enfrenta essas questões com a certeza de que a fé na ressurreição de um crucificado pelo Império romano garante que nossa luta por outro mundo possível será vitoriosa. Para fundamentar essa Esperança - que não é somente um

Resenha recebida em 26 de outubro de 2015 e aprovada em 10 de novembro de 2015.

* Doutor em Sociologia. Membro do ISER - Assessoria e da coordenação do Movimento Fé e Política. Professor aposentado da UFJF e da PUC Minas. País de origen: Brasil. E-mail: pedror.oliveira@uol.com.br. 
sonho gostoso mas uma força para a ação - ele nos oferece o livro que aqui apresento a título de resenha.

Obra planejada para a coleção "Teologia e Libertação" - cuja publicação foi bloqueada pela Cúria Romana - o livro seria o tomo referente a "Fé e Política". Passados tantos anos, o Autor retomou o projeto e nos oferece um tratado sobre o tema, tendo agora outro pano de fundo. Já não temos mais avanços nem nas lutas populares (como a revolução sandinista, o crescimento de Movimentos sociais e Partidos de esquerda, o fim do colonialismo...) nem nas Igrejas cristãs (como o florescimento das Comunidades Eclesiais de Base e Pastorais sociais, a defesa dos Direitos Humanos, o ecumenismo...), mas sim o cenário sinistro de um mundo submetido ao capitalismo globalizado e de Igrejas cristãs competindo entre si para exibir maior quantidade de adeptos. Nesse tempo de pesadelo (pois o livro foi publicado antes da eleição do Papa Francisco) Hernández Pico relê a mensagem cristã para alimentar a esperança de quem está na luta popular. E o faz com a maestria de sua sólida formação em teologia e em sociologia.

O livro é agradável de se ler, embora não seja fácil: é obra para ser estudada. Seria a leitura apropriada para os cursos de Fé e Política que hoje se multiplicam pelo Brasil, como texto de referência para seminários ou grupos em que cada participante se debruça sobre um tópico e ao final todos partilham o que leram. É portanto muito oportuna sua publicação em forma eletrônica por Amerindia (http://www.amerindiaenlared.org/biblioteca/8007/no-sea-asi-entre-ustedes-ensayo-sobre-politica-y-esperanza--juan-hernandez-pico). Seria muito oportuna, também, sua tradução em português.

O livro articula admiravelmente as duas faces da questão: a fé cristã e a política. Vejamos como o Autor trata cada uma delas separadamente, para ao final falar da espiritualidade política. 


\section{Olhar a realidade do mundo atual}

Uma análise de conjuntura feita durante a crise financeira de 2009 serve como porta de entrada para a abordagem da política. Sem otimismo nem ingenuidade, o Autor fala da vitória do capitalismo neoliberal que traz consigo a concepção do "fim da história": derrotado o socialismo soviético, não haveria mais possibilidade histórica para um sistema mundial estruturado sobre outras bases. $\mathrm{O}$ século XXI seria então o século das "histórias particulares” de uma ou outra nação que conseguisse mudar seu destino dentro do quadro capitalista em vigor. Nesse sistema, as grandes corporações transnacionais impõem seu projeto econômico aos Estados, cuja soberania é cada vez menos efetiva. Não é surpresa, portanto, o desencanto generalizado com a política, posto que o Estado não dispõe dos meios necessários para cuidar eficientemente do interesse público. Esse cenário global deixa na sombra movimentos que buscam verdadeira mudança, como são as experiências de governos de esquerda na América Latina e o Fórum Social Mundial, que o Autor coloca em relevo, por entender que fazer memória de Jesus, como ele ordenou em sua última ceia, é colocar-se ao lado das vítimas do império, às quais ele doou sua vida.

Ao assumir o lugar das vítimas do poder como ponto de referência para o estudo, o Autor inverte a perspectiva habitual que vê a política como atividade própria dos dirigentes. Ao estudar as teorias do poder a partir do lugar dos subalternos, percebe-se a outra face da política como instrumento que sofistica a dominação imposta por uma classe ou grupo ao conjunto da sociedade.

\section{Recuperar a teoria da Política}

O Autor inicia sua abordagem pelos clássicos do pensamento greco-romano. Tendo sólida formação filosófica, Hernández Pico trabalha a relação entre política, ética e educação em Sócrates, Platão e Aristóteles para explicar as origens de conceitos até hoje usados para entender as formas de governo que sustentam a vida 
na polis. O pensamento romano incorpora como categoria central o Direito que, na decadência do império combina-se com a teologia agostiniana das "duas cidades" para fundamentar o projeto da cristandade. Esse projeto está ancorado na separação entre o que é do céu e o que é da terra e postula a supremacia do celestial sobre o terrenal. O pensamento tomista desenvolve esse dualismo que culmina na ideia de Deus como governante supremo do mundo que, tendo se revelado à Igreja, confere a ela o poder de consagrar os governantes. O modelo político da cristandade medieval torna-se paradigmático como forma política de teocracia: a ordem social desejada por Deus deve ser assegurada pelo "braço secular" que é o Estado.

O Renascimento marca o início da crítica moderna ao pensamento medieval e a conquista da autonomia pelo Estado, que deixa de ser o instrumento político da Igreja. Por assim dizer, o "braço secular" deixa de ser "braço" e seculariza-se plenamente. Isso não se dá de uma hora para outra, é claro. Embora esse embate teórico tenha sido amplamente favorável à autonomia do Estado, o modelo teocrático resiste em certos grupos religiosos até nossos dias. Maquiavel inaugura esse processo de secularização do Estado no final do século $\mathrm{XV}$, ao definir a política como a arte de conquistar e exercer o poder sem curvar-se a imposições religiosas. Não por acaso sua obra ficou associada à política que hoje chamamos "de resultados" porque para ela só importa alcançar os fins almejados, não os meios empregados para isso. Quase ao mesmo tempo T. Morus publica seu livro Utopia onde apresenta outra visão da política: o governo que corresponde fielmente ao desejo de felicidade do povo não precisa de justificar-se como instrumento da vontade divina.

A partir dessa época - marcada pela expansão do capitalismo em sua forma mercantilista e pela colonização da América, África e Ásia - a política passa a ser pensada sem considerações de ordem teológica. A concepção do Direito como regulador das relações entre os povos é aplicada também à própria definição do Estado como poder soberano, única força capaz de evitar a guerra de todos contra 
todos (Hobbes). Contra essa concepção de Estado cuja força ameaça a liberdade individual, J. Locke elabora uma filosofia que vê o poder do Estado como consentido pelo conjunto de cidadãos (de fato, a burguesia emergente) para defender seus direitos (especialmente o cumprimento dos contratos e a propriedade privada). O Estado estará então indissoluvelmente associado à ordem jurídica que regula a economia e a sociedade. Esta é a base da filosofia política que será desenvolvida a partir do Iluminismo e desembocará na proposta da democracia como melhor forma de governo.

O século XVIII traz o pensamento iluminista que, no campo da política trabalha os conceitos de separação dos poderes (Montesquieu), contrato social e vontade geral (Rousseau) e democracia representativa ( $\mathrm{T}$. Jefferson e os federalistas). Hernández Pico trabalha didaticamente esses conceitos, ao mesmo tempo que coloca em evidência a relação entre direitos de cidadania e defesa da propriedade privada, tema que A. Smith desenvolverá ao estabelecer os fundamentos da Economia Política. Para concluir essa apresentação dos fundamentos da Filosofia Política, o Autor analisa as contribuições de Kant (o Estado e as condições para a paz perpétua), Hegel (a sociedade civil e o Estado de direito) e Tocqueville (a cultura como base da democracia). Por estar além de minha capacidade resumir o que é exposto sobre cada um desses gigantes da Filosofia Política, deixo apenas indicado o tema central de suas contribuições, que foram retomadas criticamente por dois clássicos das Ciências Sociais: Marx e Weber.

\section{A sociologia do poder}

Por ser impossível resumir aqui a magnífica síntese da contribuição de Marx e Engels à teoria da Política, chamo a atenção para o ponto central de sua tese: a relação entre o Estado e a sociedade de classes. Embora reconheçam a autonomia do Estado enquanto instância de poder sobre a sociedade, afirmam que ela é relativa, porque em última instância o Estado atende prioritariamente aos 
interesses das classes dominantes. Já Max Weber parte da autonomia da política enquanto relação de poder: a capacidade de impor a própria vontade sobre a vontade de outrem. Na medida em que se constitui o Estado como instituição que tem o monopólio dos meios de violência legítima - a polícia e as forças armadas ele se torna a principal referência para o grupo humano que habita o território onde é soberano. Ao longo do século XX as teorias da Política se diferenciarão pela importância conferida às relações de classe ou ao poder do Estado, como que oscilando entre Marx e Weber. Aí Hernández Pico situa as contribuições de H. Arendt (a força do indivíduo e o poder do grupo), N. Bobbio (as formas da democracia e a distinção entre direita e esquerda), M. Foucault (o poder velado das instituições) e J. Habermas (o agir comunicativo). A partir do final do século XX são tão diversas as teorias do poder, que o Autor se limita a selecionar as contribuições que ajudarão a responder à questão fundamental: como a Política impacta a vida dos pobres?

\section{Teoria Política: o olhar dos subalternos}

Se o estudo das teorias políticas tem sentido para quem quer instaurar um sistema que garanta justiça para os pobres e paz para o mundo independentemente de ser cristão ou não - é porque a perspectiva filosófica desfaz fantasias e a Sociologia e revela realidades objetivas. Elas tratam o Estado e a sociedade civil como os dois sistemas de poder que regem as relações sociais no mundo contemporâneo separadamente mas em sintonia entre si. Essa ambiguidade é o objeto da análise de Hernández Pico. Não há dúvidas de que o Estado regula a esfera pública e o faz por meio dos poderes Executivo, Legislativo e Judiciário, enquanto a sociedade civil regula a esfera privada por meio das instituições sociais como são as famílias, empresas, partidos políticos, associações, sindicatos, igrejas e todo tipo de associações voluntárias. (Cabe aqui um reparo crítico ao Autor, que menciona as diferentes instituições que regem a economia mas não aponta o mercado como principal instituição reguladora da sociedade 
civil). A controvérsia reside na relação entre esses dois sistemas de poder: a tradição marxiana assume a hipótese que a sociedade civil determina, em última instância, a ação do Estado, enquanto a tradição weberiana postula a independência de cada parte.

Embora critique severamente as aplicações do pensamento de Marx no chamado socialismo real, Hernández Pico inspira-se nele para entender como uma sociedade dividida - porque fundada na desigualdade de acesso aos bens necessários a uma vida digna - consegue subsistir. O Autor enriquece essa análise com outras contribuições teóricas (especialmente o conceito de hegemonia de A. Gramsci) e ao concluí-la afirma que a falha maior do pensamento marxiano reside em ter dado mais ênfase à teoria da transição ao socialismo, do que à teoria da saída do capitalismo.

\section{A política nas relações entre Igreja e Estado}

Depois desse longo percurso pela Filosofia e pela Sociologia do poder, Hernández Pico retorna ao tema central a partir da história das relações entre Igreja e Estado. Mostra sua institucionalização nas formas históricas de EstadoTemplo, Cristandade e Teocracia. A primeira estava em vigor na Palestina durante o tempo em que foi submetida ao Império romano, de modo que qualquer oposição ao Templo como sistema de poder (que hoje chamamos religioso) significava oposição ao Estado (que hoje vemos como político). Nesse contexto cultural, a mensagem de Jesus de Nazaré falando de Deus como o Pai que acolhe pobres e pequenos em seu Reino era, objetivamente, uma contestação ao sistema de classes e de poder da época. Os ricos e corruptos, como Zaqueu, também terão um lugar nesse Reino, mas é preciso que se convertam a um sistema de poder regido pelo amor.

Apesar da radicalidade de Jesus, no século IV a comunidade de seus seguidores e seguidoras, cansada de sofrer perseguições, integra-se nas estruturas 
do Império romano e aceita a distinção entre a auctoritas do bispo e a potestas do imperador, dando então origem à segunda forma de relação entre Igreja e Estado: a Cristandade que, para sobreviver, recorrerá vergonhosamente à guerra santa e à Inquisição até o momento em que as revoluções burguesas atingem tanto a nobreza quanto o clero. Sobrevive, então, apenas a corrente política reacionária que vê na Igreja católica a instituição desejada por Deus para instaurar no mundo a ordem cristã, como se ainda fosse viável a Teocracia.

\section{Retorno ao Evangelho}

Desmoronada a Cristandade, o Concílio Ecumênico Vaticano II abre o caminho para a volta às fontes originárias do Cristianismo e relê a vida e a mensagem de Jesus de Nazaré à luz das condições de vida do mundo contemporâneo. É então retomado o Evangelho que por séculos fora silenciado pelas autoridades eclesiásticas, dando origem a uma nova espiritualidade cristã, centrada na fé na ressurreição de um condenado pelo Templo e pelo Império. Ela afirma que os excluídos do banquete dos poderosos não estão sós: Jesus está com eles e elas, como alimento e garantia de esperança. Conclui então Hernández Pico: “o tema da relação entre fé cristã e compromisso político cai em cheio na Teologia espiritual, que dá razão à esperança” (p. 525). Ele nota que essa forma de viver a fé cristã não é a única possível, mas é sim crucial na cultura contemporânea onde certas ideologias revestem-se de argumentos religiosos para justificar a desigualdade de classes. Essa espiritualidade política encontra seu respaldo teórico na Teologia das realidades terrestres (como foi chamada na época do Concílio) que em nossa América configura-se como Teologia da Libertação.

Chegando nesse ponto, o Autor compõe sua argumentação tecendo a memória das lutas sociais e políticas sobre a trama teórica da Teologia. Intelectual e militante das causas populares, especialmente da América Central, Hernández Pico reflete sobre suas vitórias e derrotas, enfatizando certos momentos em que a participação de cristãos e cristãs ganha o caráter de martírio. Mostra como o 
processo histórico faz deslocar a atenção dos cristãos por questões intraeclesiais para a atenção pelo destino dos pobres e pessoas marginalizadas. Embora alerte contra a tentação de se desprezar outras espiritualidades cristãs ao absolutizar o próprio caminho, o Autor conclui sua análise afirmando que "é necessário, mesmo agora quando está em baixa (ele escreve antes do Papa Francisco), manter a fidelidade a esse carisma inovador que se difundiu pela Igreja dos Pobres na América Latina” (p. 553).

Para concluir, Hernández Pico faz três excelentes análises: as experiências de governos populares ou de esquerda na América Latina e Caribe (construções de pedras ou de palha?), a responsabilidade cristã pelo cuidado com a vida da Terra, e a tentação da "mosca azul" do poder (tema do livro de Fr. Betto). Em epílogo, traz um texto profético em homenagem ao bispo Girardi, de Guatemala. Trata-se de organizar a esperança: encarando os males de frente, proclamar a fé na ressurreição de uma vítima do ódio do Império, porque nela reside a esperança de ressurreição para todas as outras vítimas. Essa esperança, tão necessária quanto o pão cotidiano, é irmã gêmea da solidariedade. Juntas, elas tornam possível a construção de um mundo onde reinem a Paz e a Justiça para que venha o reinado de Deus.

\section{Conclusão}

Se a política pode ser definida como a difícil arte de possibilitar o que é necessário à vida humana, ela é uma vocação de todas as comunidades humanas, e não somente das comunidades cristãs. Animar e desenvolver a espiritualidade política é missão de toda a Igreja, mas até recentemente essa missão era mal vista pelas autoridades eclesiásticas. A inauguração do pontificado de Francisco, que fala de Igreja em saída trouxe novo alento a quem vive esse carisma espiritual na militância política. Nesse contexto, o livro de Hernández Pico é um presente de Deus a seu povo que luta e caminha em busca do Reino. Só posso agradecer ao amigo e mestre pela oportunidade dessa leitura. 